\title{
Recordando a Antonio Melis (Vignola, 1942 - La Paz, 2016)
}

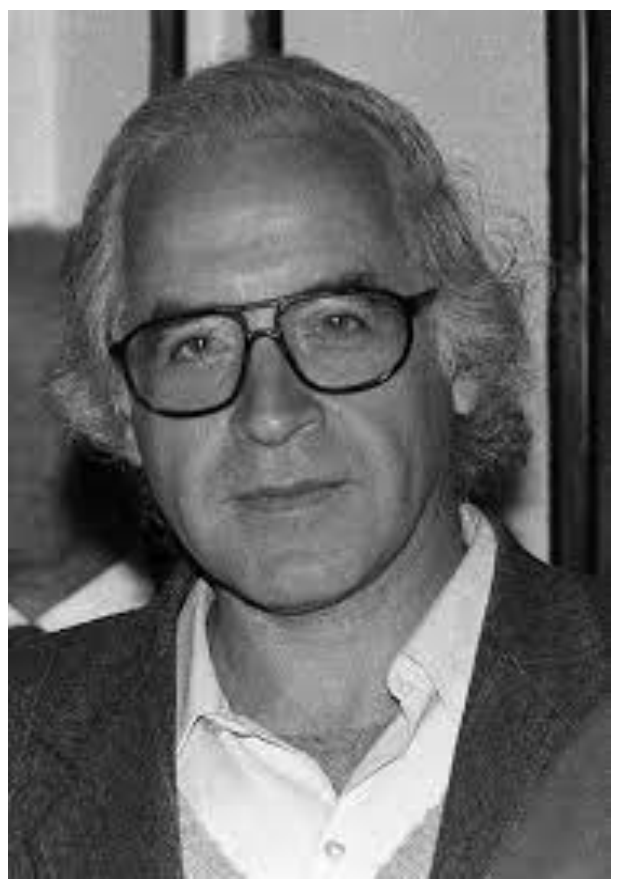

El sábado 6 de agosto de 2016 Antonio Melis y Lucia Lorenzini llegaron a La Paz para asistir a las XII Jornadas Andinas de Literatura Latinoamericana (JALLA). Antonio era uno de los "jallistas fundadores" que en 1993 habían echado a andar el proyecto intelectual de JALLA, dedicado al estudio crítico- 
descolonizador de la producción literaria y cultural de la región andina, en particular, y latinoamericana en general. La ciudad y sus habitantes los recibieron como se recibe a los hermanos que llegan de lejos, visitan a la familia y se van con la promesa de volver. Esta vez, sin embargo, la partida de Antonio fue definitiva. Al día siguiente de haber llegado, un paro cardíaco se lo llevó a lejanías desconocidas. Lucia perdió al compañero de toda una vida, JALLA a uno de sus fundadores y Secretario en Italia; el latinoamericanismo al mayor mariateguista nacido en el extranjero y orgánicamente vinculado al Perú; los estudios arguedianos al autor de José María Arguedas: poética de un demonio feliz (2011); y la Revista de Estudios Bolivianos a un insustituible miembro de su Comité Editorial. La pérdida no podía ser más honda ni más doloroso el duelo.

Sorprendente por su inteligencia, su calidad humana, su pasión por el estudio de las culturas andinas y su exquisito sentido del humor, Antonio era un ser simplemente entrañable. A los 24 años se edad descubrió en Mariátegui un norte intelectual que encauzó su reflexión crítica y lo llevó a escudriñar zonas descuidadas del espacio literario andino, generando lecturas audaces de Arguedas, Vallejo y Guaman Poma. En su intensa vida profesional se desempeñó como profesor de Lenguas y Literaturas hispanoamericanas en la Facultad de Humanidades de la Universidad de Siena, donde también impartió cursos sobre civilizaciones indígenas de América, coordinó la Maestría en Traducción Literaria y Edición de Textos y dirigió el Centro Interdepartamental de Estudios sobre América Indígena (CISAI). Entre sus contribuciones a la comunidad latinoamericanista internacional destaca su participación en el jurado de premios literarios como Casa de las Américas, Premio Juan Rulfo, Premio José Donoso, y Premio Italo Calvino; su labor como co-director (con Aníbal Quijano) de Anuario Mariateguiano y su colaboración al comité editorial de revistas especializadas como Revista de Crítica Literaria Latinoamericana, Zama Revista del Instituto de Literatura Hispanoamericana, y In Forma di Parole, donde publicó uno de sus últimos trabajos: la traducción al italiano del Ollantay.

Como peruanista y andinista, Antonio fue Profesor Honorario de la Universidad Nacional Mayor de San Marcos de Lima. Sus contribuciones a la literatura peruana contemporánea incluyen numerosos estudios y traducciones de poetas como Martín Adán, Carlos Germán Belli, Alejandro Romualdo, César Calvo, Luis Hernández, Antonio Cisneros y José Luis Ayala. Paralelamente a estos trabajos, se interesó por los procesos culturales antillanos y centroamericanos, particularmente por la obra de José Martí, 
Fernando Ortíz y Alejo Carpentier. En ese contexto, tradujo gran parte de la obra poética de Ernesto Cardenal. La seducción de la traducción lo llevó también a integrar un equipo encargado de preparar, para la editorial Adelphi de Milan, una nueva edición italiana de la obra completa de Borges. Refiriéndose a ese proyecto, Antonio hizo una observación conmovedora:

Para quien sepa escuchar las razones del autor traducido, el "rigor resignado" del que hablaba Borges en el caso de Whitman puede transformarse en un momento de felicidad. Es la que yo, Pierre Menard, he probado acogiendo en mi idioma italiano Ficciones. Espero haber transmitido algo de esta felicidad a los lectores de $\mathrm{mi}$ versión. ("Pierre Menard, traductor de Borges")

Donde sea que estés, Antonio, queremos hacerte saber que no solo tus traducciones, sino tu obra en su conjunto transmite esa felicidad con la que has vivido tu vida y dignificado la profesión. Esa felicidad que, como a "un demonio feliz", te empujaba a cantar en quechua y a tender puentes de amistad entre culturas y civilizaciones.

Bolivian Studies Journal - Revista de Estudios Bolivianos

$($ (c) $)$ EY

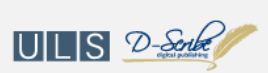

This work is licensed under a Creative Commons Attribution 3.0 United States License.

This journal is published by the University Library System of the University of Pittsburgh as part of its D-Scribe Digital Publishing Program, and is cosponsored by the University of Pittsburgh Press. 